\title{
Biochar alters nitrogen transformations but has minimal effects on nitrous oxide emissions in an organically managed lettuce mesocosm
}

\author{
Engil Isadora Pujol Pereira ${ }^{1} \cdot$ Emma C. Suddick $^{2} \cdot$ India Mansour $^{3}$. \\ Fungai N. D. Mukome ${ }^{3}$ - Sanjai J. Parikh ${ }^{3} \cdot$ Kate Scow $^{3}$ - Johan Six ${ }^{1}$
}

Received: 13 November 2014 /Revised: 9 February 2015 / Accepted: 8 March 2015 /Published online: 19 March 2015

(C) Springer-Verlag Berlin Heidelberg 2015

\begin{abstract}
We investigated the effect of biochar type on plant performance and soil nitrogen $(\mathrm{N})$ transformations in mesocosms representing an organic lettuce (Lactuca sativa) production system. Five biochar materials were added to a silt loam soil: Douglas fir wood pyrolyzed at $410{ }^{\circ} \mathrm{C}$ (W410), Douglas fir wood pyrolyzed at $510{ }^{\circ} \mathrm{C}$ (W510), pine chip pyrolyzed at $550^{\circ} \mathrm{C}(\mathrm{PC})$, hogwaste wood pyrolyzed between 600 and $700{ }^{\circ} \mathrm{C}$ (SWC), and walnut shell gasified at $900{ }^{\circ} \mathrm{C}$ (WS). Soil $\mathrm{pH}$ and cation exchange capacity were significantly increased by WS biochar only. Gross mineralization increased in response to biochar materials with high $\mathrm{H} / \mathrm{C}$ ratio (i.e., W410, W510, and SWC), which can be favorable for organic farming systems challenged by insufficient $\mathrm{N}$ mineralization during plant growth. Net nitrification was increased by W510, PC, and WS without correlating with the abundance of ammonia oxidizing gene (amoA). Increases in $\mathrm{N}$ transformation rates did not translate into increases in plant productivity or leaf $\mathrm{N}$ content. WS biochar increased the abundance of amo $A$ and nitrite reductase gene (nirK), while SWC biochar decreased the abundance of amoA and nitrous oxide gene (nosZ). Decreases in $\mathrm{N}_{2} \mathrm{O}$ emissions were only observed in soil amended with W510 for 3 days out of the 42-day growing season without affecting total cumulative $\mathrm{N}_{2} \mathrm{O}$ fluxes. This
\end{abstract}

Dr. Engil Isadora Pujol Pereira

engil.pereira@usys.ethz.ch

1 Department of Environmental Systems Sciences, Institute of Agricultural Sciences, Swiss Federal Institute of Technology, Tannenstrasse 1, 8092 Zurich, Switzerland

2 Woods Hole Research Center, 149 Woods Hole Road, Falmouth, MA 02450, USA

3 Department of Land, Air, and Water Resources, University of California, Davis, One Shields Avenue, Davis, CA 95616, USA suggests that effects of biochar on decreasing $\mathrm{N}_{2} \mathrm{O}$ emissions may be transient, which compromise biochar's potential to be used as a $\mathrm{N}_{2} \mathrm{O}$ mitigation strategy in organic systems. Overall, our results confirm that different biochar materials can distinctively affect soil properties and $\mathrm{N}$ turnover.

Keywords Mineralization · Nitrification · Functional gene abundance $\cdot$ Lettuce $\cdot$ Organic farming .

Greenhouse gas emissions

\section{Introduction}

Managing nitrogen $(\mathrm{N})$ dynamics represents a challenge for organic cropping systems. In particular, sufficient $\mathrm{N}$ mineralization is not always achieved; timing of $\mathrm{N}$ release and plant uptake is often not synchronized (Pang and Letey 2000), and subsequent $\mathrm{N}$ transformations of mineralized $\mathrm{N}$ may be released to the atmosphere as nitrous oxide $\left(\mathrm{N}_{2} \mathrm{O}\right)$, a potent greenhouse gas. Emissions of $\mathrm{N}_{2} \mathrm{O}$ are responsible for $61 \%$ of agricultural greenhouse gas (GHG) emissions and are mainly related to $\mathrm{N}$ fertilization in field crop agriculture (Montzka et al. 2011). A meta-analysis by Tuomisto et al. (2012) reported that, compared to conventional systems, $\mathrm{N}_{2} \mathrm{O}$ emissions were $31 \%$ lower in organic systems when the impact was allocated per unit of field area but $8 \%$ higher when the impact was allocated per unit of end product. The increasing market demand for organic food calls for an intensification and expansion of this production system (Li et al. 2007; Niggli et al. 2008; Willer and Kilcher 2012). Hence, organic farmers are challenged to increase yields without causing additional environmental harm.

One alternative proposed to increase $\mathrm{N}$ use efficiency and reduce $\mathrm{N}_{2} \mathrm{O}$ emissions from soils is the amendment with biochar. The term "biochar" defines the charcoal obtained from 
the intended thermal conversion of waste biomass into energy in processes such as pyrolysis and gasification (Spokas et al. 2012). When amended to soils, biochar may alter many soil properties such as soil $\mathrm{pH}$, cation exchange capacity (CEC), moisture content, and microbial activity that intrinsically regulate $\mathrm{N}$ transformations (Clough and Condron 2010; Clough et al. 2013). Studies have often linked increases in plant productivity and $\mathrm{N}$ uptake with an increased $\mathrm{N}$ availability in biochar-amended soils due to high $\mathrm{N}$ retention by cation exchange capacity (Chan et al. 2008a; Chan et al. 2008b; Steiner et al. 2007). A practice that improves plant $\mathrm{N}$ uptake would be very advantageous to organic farming systems challenged by the restrictions of using organically sourced $\mathrm{N}$.

A growing number of studies demonstrate decreases in $\mathrm{N}_{2} \mathrm{O}$ emissions associated with the effects of biochar on $\mathrm{N}$ availability, increases in soil $\mathrm{pH}$, or aeration soil structure. Studies that relate decrease in $\mathrm{N}_{2} \mathrm{O}$ emissions with lower inorganic $\mathrm{N}$ availability report either increased microbial $\mathrm{N}$ immobilization or decreased nitrification rates (Wang et al. 2011; Cayuela et al. 2013). Other reports suggest that the elevated soil $\mathrm{pH}$ resulting from biochar amendment enhances $\mathrm{N}_{2} \mathrm{O}$ reductase activity and thus promotes $\mathrm{N}_{2}$ formation and higher $\mathrm{N}_{2} / \mathrm{N}_{2} \mathrm{O}$ ratios (Clough and Condron 2010; Singh et al. 2010; Zheng et al. 2012). Finally, the highly porous structure of biochar can increase soil aeration, thereby reducing anaerobic sites for $\mathrm{N}_{2} \mathrm{O}$ production (Yanai et al. 2007; Rogovska et al. 2011). However, studies also have documented that amendments with biochar lead to $\mathrm{N}_{2} \mathrm{O}$ increases (Clough et al. 2010; Bruun et al. 2011; Saarnio et al. 2013, Singla et al. 2014, Verhoeven and Six 2014) and null effects (Castaldi et al. 2011; Karhu et al. 2011; Scheer et al. 2011; Suddick and Six 2013). Given such a variety of $\mathrm{N}_{2} \mathrm{O}$ responses to biochar amendment, it is likely that effects vary with biochar materials (Guerrero et al. 2005), and soil and fertilization management (Spokas and Reicosky 2009).

To detect whether biochar can effectively increase $\mathrm{N}$ availability and plant productivity, as well as reduce $\mathrm{N}_{2} \mathrm{O}$ emissions, we monitored these parameters in microcosms amended with five different biochar materials during the production of organic lettuce. We also assessed the abundance of N-cycling microorganisms by targeting functional bacterial genes that encode for enzymes involved in ammonia oxidation (amoA) and nitrite (nirK and nirS) and $\mathrm{N}_{2} \mathrm{O}$ reduction (nosZ).

\section{Materials and methods}

\section{Greenhouse bioassay description}

The experiments were carried out at the Environmental Horticulture Greenhouse Facility, University of California, Davis. Lettuce (Lactuca sativa) was grown for 42 days under a constant temperature of $25^{\circ} \mathrm{C}$ in the greenhouse. Plants were grown under mesocosm conditions that explicitly simulated field conditions in terms of irrigation and organic fertilization management. Six different biochar treatments were used in this study: control (no amendment), Douglas fir wood pyrolyzed at $410{ }^{\circ} \mathrm{C}$ (W410), Douglas fir wood pyrolyzed at $510^{\circ} \mathrm{C}$ (W510), pine chip pyrolyzed at $550^{\circ} \mathrm{C}(\mathrm{PC})$, hogwaste wood pyrolyzed between 600 and $700^{\circ} \mathrm{C}(\mathrm{SWC})$, and walnut shell gasified at $900{ }^{\circ} \mathrm{C}$ (WS) (Table 1). Mesocosms were arranged in a completely randomized design that consisted of 19-L pots as experimental units with three replicates per treatment. The pots were filled with the A horizon of a Yolo silt loam soil $(0-15 \mathrm{~cm})$ to a depth of $20 \mathrm{~cm}$. Soil was collected from the riparian zone of the Century Experiment at Russell Ranch Sustainable Agriculture Facility, Davis, CA. This soil is approximately $46 \%$ sand, $32 \%$ silt, and $22 \%$ clay with a $\mathrm{pH}$ of $6.7,7.30 \mathrm{~g} \mathrm{C} \mathrm{kg}^{-1}$ soil, and $0.82 \mathrm{~g} \mathrm{~N} \mathrm{~kg}^{-1}$ soil. The soil was sieved $(<8 \mathrm{~mm})$ and amended with fertilizer and biochar. The biochar was applied at a rate equivalent to 10 metric $\mathrm{tha}^{-1}$. The fertilization rate was split into two applications of $95 \mathrm{~kg} \mathrm{~N} \mathrm{ha}^{-1}$ spaced by 30 days from each other using a compost mix of animal and plant manure. The plants received daily irrigation and soil moisture was maintained at about $20 \%$ $(w / w)$. Dry biomass $\left(60^{\circ} \mathrm{C}, 7\right.$ days) was recorded. Plant tissues were ball milled before $\mathrm{N}$ concentrations were analyzed by combustion (Costech Instruments ECS 4010). Nitrogen use efficiency (NUE) was calculated as the amount of $\mathrm{N}$ uptake by plants per kilogram of $\mathrm{N}$ supplied through fertilization.

\section{Biochar and soil characterization}

Table 1 shows some physicochemical properties of the biochar materials, and a complete characterization can be found in Mukome et al. (2013). Biochar and soil pH were measured in deionized water using a 1:2 and 1:1 $(w / w)$ ratio, respectively, with an equilibration time of $1 \mathrm{~h}$. The $\mathrm{pH}$ was measured on an Orion 4 Star, Thermo Fisher Scientific $\mathrm{pH}$ meter. Ash content of biochar materials was determined according to ASTME 1755-95 (1995).

Cation exchange capacity (CEC) measurements of biochar and soil samples were adapted from Mulvaney et al. (2004) and Gaskin et al. (2008). Following Mukome et al. (2013), for each sample, $0.5 \mathrm{~g}$ of biochar or soil was weighed into a solid phase column and $30 \mathrm{~mL}$ of $1 \mathrm{M} \mathrm{NaOAc}$ was added to the column, which was then vacuum-filtered. The samples were washed with $30 \mathrm{~mL}$ of isopropanol to remove excess sodium (Na). Sodium ions were displaced with $\mathrm{NH}_{4} \mathrm{OAc}(\mathrm{pH} 7)$ three times and measured by atomic adsorption spectroscopy at the UC Davis Analytical Laboratory. Biochar C, H, and N concentrations were determined by combustion at Galbraith Laboratories, Inc. (Knoxville, TN, USA). C input to respective treatment is presented in Table 1. Samples for measurement of $\mathrm{pH}, \mathrm{CEC}, \mathrm{N}$ transformation processes, and functional 
Table 1 Feedstock, production temperature, and selected physicochemical properties of the biochar materials

\begin{tabular}{llllllllll}
\hline Biochar material & Feedstock & $\begin{array}{l}\text { Production temperature } \\
\left({ }^{\circ} \mathrm{C}\right)\end{array}$ & $\mathrm{pH}$ & $\begin{array}{l}\text { Ash } \\
(\%)\end{array}$ & $\begin{array}{l}\mathrm{N} \\
(\%)\end{array}$ & $\begin{array}{l}\mathrm{C} \\
(\%)\end{array}$ & $\begin{array}{l}\mathrm{H} / \mathrm{C} \\
\text { ratio }\end{array}$ & $\begin{array}{l}\mathrm{C} \text { input } \\
\left(\mathrm{metric} \mathrm{ton} \mathrm{ha}^{-1}\right)\end{array}$ & $\begin{array}{l}\mathrm{CEC} \\
\left(\mathrm{meq}^{100} \mathrm{~g}^{-1}\right)\end{array}$ \\
\hline Douglas fir (W410) & Softwood & 410 & 7.1 & 2.6 & 0.21 & 83.9 & 0.8 & 8.39 & 10.0 \\
Douglas fir (W510) & Softwood & 510 & 7.3 & 3.0 & 0.36 & 65.7 & 0.27 & 6.57 & 12.0 \\
Pine chip (PC) & Wood chips & 550 & 7.9 & 17 & 0.91 & 71.2 & 0.47 & 7.12 & 3.2 \\
Soft wood chips (SWC) & Softwood & $600-700$ & 7.5 & 2.4 & 0.51 & 68.2 & 0.64 & 6.82 & 26.2 \\
Walnut shell biochar (WS) & Walnut shell & 900 & 9.7 & 40.4 & 0.47 & 55.3 & 0.19 & 5.53 & 33.4 \\
\hline
\end{tabular}

CEC cation exchange capacity

gene assessments were collected from mesocosms $(0-10-\mathrm{cm}$ depth) during the harvest of lettuce.

\section{DNA extraction}

Soil samples for DNA extractions were stored $\left(-80^{\circ} \mathrm{C}\right)$ for 3 weeks until DNA extractions. DNA was extracted from 0.5g aliquots of soil using the FastDNA Spin Kit for Soil (MP Biomedicals, Illkirch, France). To improve DNA quality, an additional cleaning step was performed with the addition of $5.5 \mathrm{M}$ guanidine isothiocyanate (Porteous et al. 1994). Final DNA extracts were stored at $-20{ }^{\circ} \mathrm{C}$ before analysis using real-time (RT) PCR. The concentration of DNA in the extracts was determined using Qubit with Quant-iT dsDNA HS Assay Kits (Invitrogen, Carlsbad, CA, USA). DNA purity was determined using a NanoDrop spectrophotometer (Thermo Scientific, Wilmington, DE) by measuring the $\mathrm{A}_{260 \mathrm{~nm}} /$ $\mathrm{A}_{280 \mathrm{~nm}}$ absorbance ratio.

\section{Real-time quantitative PCR assay}

Abundances of total bacteria, nitrifier, and denitrifiers were estimated by real-time qPCR targeting of universal bacterial gene (16S rDNA), ammonia monooxygenase gene (amoA), nitrite reductase genes (nirK and nirS), and nitrous oxide reductase gene (nosZ), respectively. All genes were amplified using an Applied Biosystems 7300 Real-Time PCR system (Foster City, CA, USA), with three analytical replicates per sample, and references are shown in Table 2.

The quantification of the 16S rDNA gene used to estimate the total bacterial abundance was performed using $4 \mu \mathrm{L}$ of template DNA, $10 \mu \mathrm{L}$ of TaqMan Universal PCR Master Mix (Applied Biosystems, Foster City, CA, USA), $4 \mu \mathrm{L}$ of $\mathrm{H}_{2} \mathrm{O}, 800 \mathrm{nM}$ each of forward and reverse primers, and $0.4 \mu \mathrm{L}$ of the fluorogenic probe (TM1389: 50-CTT GTA CAC ACC GCC CGTC-30; $200 \mathrm{nM}$ ) (Suzuki et al. 2000). Real-time quantitative PCR of the amo $A$ gene was performed using $5 \mu \mathrm{L}$ of template DNA, $10 \mu \mathrm{L}$ of ABI Power SYBR Green PCR (Applied Biosystems, Foster City, CA, USA), and $0.3 \mu \mathrm{M}$ of the A189 forward and $0.9 \mu \mathrm{M}$ of the amoA-2R' reverse primers (Okano et al. 2004). Real-time quantitative
PCR of the nirK gene was performed using $5 \mu \mathrm{L}$ of template DNA, $12.5 \mu \mathrm{L}$ of ABI Power SYBR Green PCR Master Mix, and $0.5 \mu \mathrm{M}$ each of forward and reverse primers (Henry et al. 2004). NirS gene was also amplified by using $5 \mu \mathrm{L}$ of template DNA, $12.5 \mu \mathrm{L}$ of ABI Power SYBR Green PCR Master Mix, and $0.5 \mu \mathrm{M}$ each of forward and reverse primers (Throbäck et al. 2004; Kandeler et al. 2006). For the nosZ gene, qPCR was performed using $5 \mu \mathrm{L}$ of template DNA, $10 \mu \mathrm{L}$ of ABI Power SYBR Green PCR Master Mix, and $0.3 \mu \mathrm{M}$ each of forward and reverse primers (Henry et al. 2006).

Standard curves were generated for each gene by using serial dilutions of a standard containing a known number of the target sequences. To prepare the $16 \mathrm{~S}$ standard, we used the pT7Blue-3 Perfectly Blunt ${ }^{\circledR}$ Cloning Kit and pT7Blue-3 vector (EMD Millipore, Bedford, MA, USA). The 16S rDNA fragment was amplified from Escherichia coli (strain K-12). To prepare standards for the $\mathrm{N}$ cycling genes, we used TOPO TA cloning kit with pCR2.1-TOPO TA cloning vector and OneShot TOP10 chemically competent $E$. coli (Invitrogen, Carlsbad, CA, USA). DNA was extracted with a Plasmid Mini Kit (Qiagen) from four transformants containing amoA (GenBank: Z97833), nirK (GenBank: NC003037.1), nirS (GenBank: AF197466.1), and nosZ (GenBank: AF197468); gene fragments were amplified from Nitrosomonas europaea (ATCC 19718), Sinorhizobia meliloti, Pseudomonas fluorescens, and Bradyrhizobium japonicum (strain USDA 110 ), respectively. The concentration of plasmid DNA was quantified spectrofluorometrically using the Quant-iT fluorescent dye method (Molecular Probes, Invitrogen, Paisley, UK). Standard curves were linear over 5 orders of magnitude, and the detection limit was approximately 100 copies for the amoA, nirK, nirS, and nosZ real-time qPCRs and 1000 copies for the 16S rDNA real-time qPCR $\left(r^{2}>0.98\right)$. The number of copies of 16S rDNA, amoA, nirS, nirK, and nosZ in soil extracts was calculated from the respective concentrations of extracted plasmid DNA.

We also calculated the ratios between the abundances of nitrite reductase genes (nirK and nirS) and nitrous oxide gene (nosZ) to detect any changes in the compostion of producers and reducer of $\mathrm{N}_{2} \mathrm{O}$, respectively. We report ratios of "nirK/ nos $Z$," "nirS/nosZ," and "nirK+nirS/nosZ" abundances 
Table 2 Primer sets and thermal profiles used for quantification of total bacterial gene (16S rDNA) and functional genes involved in the N cycle (amoA, nirK, nirS, and nosZ)

\begin{tabular}{|c|c|c|c|c|}
\hline & Primer/probe & Primer sequence $\left(5^{\prime}-3^{\prime}\right)$ & Thermal profile & Reference \\
\hline 16S rDNA & $\begin{array}{l}\text { BACT1369F } \\
\text { PROK1492R } \\
\text { TM1389 }\end{array}$ & $\begin{array}{l}\text { CGGTGAATACGTTCYCGG } \\
\text { AAGGAGGTGATCCRGCCGCA } \\
\text { CTTGTACACACCGCCCGTC }\end{array}$ & $\begin{array}{l}50{ }^{\circ} \mathrm{C}, 2 \mathrm{~min}, 95^{\circ} \mathrm{C}, 10 \mathrm{~min} \\
40 \text { cycles: } 95^{\circ} \mathrm{C}, 15 \mathrm{~s}, 56{ }^{\circ} \mathrm{C}, 60 \mathrm{~s}\end{array}$ & Suzuki et al. (2000) \\
\hline Bact. amoA & $\begin{array}{l}\text { amoA189F } \\
\text { amoA-2R' }\end{array}$ & $\begin{array}{l}\text { GNG ACT GGG ACT TCT GG } \\
\text { CCC CTC KGS AAA GCC TTC TTC }\end{array}$ & $\begin{array}{l}15 \mathrm{~s} \text { at } 95{ }^{\circ} \mathrm{C}, 40 \text { cycles: } 95^{\circ} \mathrm{C}, 15 \mathrm{~s} \\
55^{\circ} \mathrm{C}, 15 \mathrm{~s}, 72{ }^{\circ} \mathrm{C}, 31 \mathrm{~s} \\
95^{\circ} \mathrm{C}, 15 \mathrm{~s}, 60{ }^{\circ} \mathrm{C}, 30 \mathrm{~s}, 95^{\circ} \mathrm{C}, 15 \mathrm{~s}\end{array}$ & Okano et al. (2004) \\
\hline $\operatorname{nirK}$ & $\begin{array}{l}\text { nirK876 } \\
\text { nirK1040 }\end{array}$ & $\begin{array}{l}\text { ATYGGCGGVCAYGGCGA } \\
\text { GCCTCGATAGRTTRTGGTT }\end{array}$ & $\begin{array}{l}95{ }^{\circ} \mathrm{C}, 30 \mathrm{~s}, 5 \text { cycles: } 95{ }^{\circ} \mathrm{C}, 15 \mathrm{~s}, 63-59{ }^{\circ} \mathrm{C} \\
\left(-1{ }^{\circ} \mathrm{C} \text { per cycle }\right), 30 \mathrm{~s}, 72{ }^{\circ} \mathrm{C}, 30 \mathrm{~s}, 30 \text { cycles: } \\
95^{\circ} \mathrm{C}, 15 \mathrm{~s}, 63{ }^{\circ} \mathrm{C}, 30 \mathrm{~s}, 72{ }^{\circ} \mathrm{C}, 30 \mathrm{~s}\end{array}$ & Henry et al. (2004) \\
\hline nirs & $\begin{array}{l}\text { nirSCd3aF } \\
\text { nirSR3cd }\end{array}$ & $\begin{array}{l}\text { AACGYSAAGGARACSGG } \\
\text { GASTTCGGRTGSGTCTTSAYGAA }\end{array}$ & $\begin{array}{l}95^{\circ} \mathrm{C}, 10 \text { min, } 35 \text { cycles: } 95^{\circ} \mathrm{C}, 15 \mathrm{~s}, 63^{\circ} \mathrm{C} \text {, } \\
30 \mathrm{~s}, 72{ }^{\circ} \mathrm{C}, 30 \mathrm{~s}, 80{ }^{\circ} \mathrm{C}, 30 \mathrm{~s}\end{array}$ & $\begin{array}{l}\text { Throbäck et al. (2004) } \\
\text { Kandeler et al. (2006) }\end{array}$ \\
\hline $\operatorname{nos} Z$ & $\begin{array}{l}\operatorname{nosZ2F} \\
\operatorname{nosZ2R}\end{array}$ & $\begin{array}{l}\text { CGC RAC GGC AAS AAG GTS MSS GT } \\
\text { CAK RTG CAK SGC RTG GCA GAA }\end{array}$ & $\begin{array}{l}95{ }^{\circ} \mathrm{C}, 10 \text { min } 6 \text { cycles: } 95{ }^{\circ} \mathrm{C}, 15 \mathrm{~s}, 65^{\circ} \mathrm{C}, \\
30 \mathrm{~s}, 72{ }^{\circ} \mathrm{C}, 30 \mathrm{~s}, 40 \text { cycles: } 95{ }^{\circ} \mathrm{C}, 15 \mathrm{~s}, \\
60{ }^{\circ} \mathrm{C}, 15 \mathrm{~s}, 72{ }^{\circ} \mathrm{C}, 30 \mathrm{~s}, 83{ }^{\circ} \mathrm{C}, 30 \mathrm{~s}\end{array}$ & Henry et al. (2006) \\
\hline
\end{tabular}

${ }^{\text {a }}$ Fluorogenic probe, labeled with FAM and BHQ1 at the 5'- and 3'-ends, respectively

because no one bacterium possesses both the copper-based (nirK) and the heme-based (nirS) nitrite reductases (Throbäck 2006). Additionally, to our knowledge, it is difficult to predict the representative nitrite reductase gene for a specific environment and the factors that induce changes in the abundance of nirK or nirS.

\section{Soil N transformations}

We quantified gross mineralization and nitrification rates using ${ }^{15} \mathrm{~N}$ pool dilution techniques (Barraclough 1991). In brief, for each mesocosm replicate, we re-wetted four 10-g soil subsamples with solutions of $\left({ }^{15} \mathrm{NH}_{4}\right)_{2} \mathrm{SO}_{4}$ (99 at.\%) for potential gross mineralization incubations and $\mathrm{K}^{15} \mathrm{NO}_{3}$ (99 at.\%) for potential gross nitrification. The addition of the

${ }^{15} \mathrm{~N}$ solutions resulted in an approximate soil moisture level of $60 \%$ water-holding capacity (WHC). The amount of ${ }^{15} \mathrm{~N}$ added to each replicate was adjusted to achieve approximately 10 at. $\%{ }^{15} \mathrm{~N}$ enrichment. For the potential gross mineralization assay, two subsamples were incubated for $3 \mathrm{~h}\left(t_{0}\right)$ and 1 day $\left(t_{1}\right)$. For the gross nitrification measurement, the two remaining replicates were incubated for $3 \mathrm{~h}\left(t_{0}\right)$ and 3 days $\left(t_{3}\right)$. After the incubation period, samples were extracted with $2 \mathrm{M}$ $\mathrm{K}_{2} \mathrm{SO}_{4}$ and pool sizes of $\mathrm{NH}_{4}{ }^{+}-\mathrm{N}$ and $\mathrm{NO}_{3}{ }^{-}-\mathrm{N}$ were estimated colorimetrically by using the Berthelot reaction for $\mathrm{NH}_{4}{ }^{+}-\mathrm{N}$ (Forster 1995) and the vanadium (III) chloride reduction method for $\mathrm{NO}_{3}{ }^{-}-\mathrm{N}$ (Doane and Horwáth 2003). The samples were diffused onto acidified disks (Stark and Hart 1996), and the ${ }^{15} \mathrm{~N}$ isotopic signatures of $\mathrm{NH}_{4}{ }^{+}-\mathrm{N}$ and $\mathrm{NO}_{3}{ }^{-}-\mathrm{N}$ were analyzed with a PDZ Europa 20-20 isotope ratio mass spectrometer (Crewe, UK; Stable Isotope Facility of the University of California, Davis). Rates for gross mineralization and nitrification rates were calculated from the rate at which the relative abundance of ${ }^{15} \mathrm{~N}$ and the size of the $\mathrm{NH}_{4}{ }^{+}-\mathrm{N}$ and $\mathrm{NO}_{3}{ }^{-}-\mathrm{N}$ pool changed over time (Barraclough 1991):

$m=\theta \times\left[\frac{\log \left(A_{0}^{*} / A_{t}^{*}\right)}{\log \left[(1+\theta t) / C_{0}\right]}\right]$

where $m=$ potential gross mineralization or nitrification rate, $\theta=$ the rate of change in the size of the $\mathrm{NH}_{4}^{+}$or $\mathrm{NO}_{3}{ }^{-}$pool, $A_{0}^{*}=$ the ${ }^{15} \mathrm{~N}$ at. $\%$ excess of the $\mathrm{NH}_{4}{ }^{+}$or $\mathrm{NO}_{3}{ }^{-}$ pool at $t_{0}, A_{t}^{*}=$ the ${ }^{15} \mathrm{~N}$ at. $\%$ excess of the $\mathrm{NH}_{4}{ }^{+}$or $\mathrm{NO}_{3}{ }^{-}$pool at $t_{1}$ or $t_{3}$, respectively, and $C_{0}=$ the size of the $\mathrm{NH}_{4}{ }^{+}$or $\mathrm{NO}_{3}{ }^{-}$ pool at $t_{0}$.

Net nitrification rates were estimated by incubating $50 \mathrm{~g}$ air-dried soil for 7 days. The moisture of the soil samples was brought to $60 \%$ WHC on the first day of incubation. $\mathrm{NH}_{4}{ }^{+}-\mathrm{N}$ and $\mathrm{NO}_{3}{ }^{-}-\mathrm{N}$ of two 10 -g subsamples were extracted at the first and seventh day of incubation using the same extraction and quantification methods described above for the gross mineralization and nitrification rate measurements.

\section{Nitrous oxide fluxes}

Nitrous oxide evolved from soil was sampled by an adapted vented-closed-flux chamber made of polypropylene material. These chambers (0.33-m height by $0.18-\mathrm{m}$ diameter) securely fit on to the pots to create an airtight seal. At sampling time, gas samples $(20 \mathrm{~mL})$ were drawn from the headspace of the chambers with $25-\mathrm{mL}$ polypropylene syringes and transferred into 12-mL pre-evacuated exetainers $0,20,40$, and $60 \mathrm{~min}$ after the chambers were closed. Samples were taken two times a week or for 7 days after each fertilization event over the 42 day growth period. $\mathrm{N}_{2} \mathrm{O}$ fluxes were analyzed by electron capture gas chromatography (GC-2014 Shimadzu Gas 
Chromatograph, Kyoto, Japan). Gas concentrations were tested for linearity (Hutchinson and Mosier 1981) to determine the best flux and finally converted to $\mathrm{g} \mathrm{N}_{2} \mathrm{O}-\mathrm{N} \mathrm{ha}^{-1}$ day ${ }^{-1}$. The cumulative $\mathrm{N}_{2} \mathrm{O}$ emissions across the biochar materials were calculated by interpolating the emissions between each sampling day.

\section{Data analyses}

Gross mineralization, gross nitrification, net nitrification, and copy number of $16 \mathrm{~S}$ rDNA, amo A, nirK, nirS, and nos $Z$ genes were analyzed by one-way analysis of variance (ANOVA). For cumulative $\mathrm{N}_{2} \mathrm{O}$ fluxes, we performed a mixed model (PROC MIXED, SAS) between treatments and sampling date with repeated-measures ANOVA to determine differences between biochar amendment and control across time. Dunnett post hoc analysis was used to compare the treatment against the control. When data were not normally distributed or showed heterogeneity of variances, they were logtransformed before analysis. Pearson correlation analysis (PROC CORR Pearson, SAS) was used to examine the relationships among functional gene abundance, soil, and biochar properties. All analyses were performed using SAS statistical package.

\section{Results}

\section{Soil properties and plant performance}

Soil $\mathrm{pH}$ was significantly increased only by WS biochar (Table 4) whose $\mathrm{pH}$ is the highest among the biochar materials used in this study. Correlation analyses indicate that soil $\mathrm{pH}$ correlated well with biochar $\mathrm{pH}$ and ash content (Table 5). WS biochar also increased significantly soil CEC by $64 \%$ relative to the control (Table 4), likely due to increases in soil $\mathrm{pH}$. Although changes in soil properties were observed, none of the biochar amendments altered plant performance indicators, such as plant biomass, leaf $\mathrm{N}$ concentration, and $\mathrm{N}$ use efficiency (Table 3).

\section{$\mathrm{N}$ transformations and nitrous oxide emissions}

Gross mineralization rates were increased by W410, W510, and SWC (Table 4). The highest gross mineralization rate was observed by the W410 biochar treatment, which was more than two times that of control. Gross mineralization rates were positively correlated with biochar $\mathrm{H} / \mathrm{C}$ ratio (Table 5). Gross nitrification rates were not affected by any of the biochar materials and did not correlate with any of the variables measured. Soils amended with WS, PC, and W510 doubled net nitrification, while W410 and SWC did not alter net
Table 3 Dry matter, leaf $\mathrm{N}$ concentration, and nitrogen use efficiency (NUE) in lettuce plants grown in soils amended with different biochar amendments

\begin{tabular}{llll}
\hline & Dry matter $\left(\mathrm{g} \mathrm{plant}^{-1}\right)$ & Leaf N $\left(\mathrm{mg} \mathrm{g}^{-1}\right)$ & NUE (\%) \\
\hline Control & $12.6 \pm 0.6$ & $26.5 \pm 1.3$ & $29.4 \pm 2.9$ \\
W410 & $14.7 \pm 0.9$ & $31.9 \pm 3.2$ & $41.3 \pm 5.7$ \\
W510 & $13.3 \pm 1.7$ & $31.6 \pm 3.4$ & $36.3 \pm 3.9$ \\
PC & $12.4 \pm 2.6$ & $32.3 \pm 8.2$ & $31.6 \pm 0.8$ \\
SWC & $10.9 \pm 1.9$ & $29.9 \pm 5.0$ & $27.3 \pm 2.1$ \\
WS & $12.5 \pm 1.0$ & $28.1 \pm 0.8$ & $30.6 \pm 1.7$ \\
\hline
\end{tabular}

Values are means \pm standard errors $(n=3)$ with no statistical differences between the means $(p<0.05)$.

nitrification. Net nitrification was negatively correlated with biochar $\mathrm{H} / \mathrm{C}$ ratio.

None of the biochar materials affected the total cumulative $\mathrm{N}_{2} \mathrm{O}$ emissions (Table 4), which averaged $0.48 \mathrm{~kg} \mathrm{~N}_{2} \mathrm{O}$ $\mathrm{N}$ ha ${ }^{-1}$ over the 42-day growing season. However, biochar material W510 significantly decreased $\mathrm{N}_{2} \mathrm{O}$ emissions for a short time of the growth period (Fig. 1b). W510 had lower cumulative $\mathrm{N}_{2} \mathrm{O}$ fluxes for three consecutive days after the second application of fertilizer compared to the control ( $p$ values $=0.048,0.026$, and 0.042 ). We did not observe any changes in $\mathrm{N}_{2} \mathrm{O}$ emissions in the remaining biochar treatments across the growing period compared to the control. Total cumulative emissions of $\mathrm{N}_{2} \mathrm{O}$ did not correlate with any of the studied parameters.

\section{Total bacterial, nitrifier, and denitrifier community abundances}

The abundance of $16 \mathrm{~S}$ rDNA and $\mathrm{N}$ cycling genes in biocharamended soil is presented in Table 6 . The abundance of total bacteria estimated by $16 \mathrm{~S}$ rDNA gene was not affected by the biochar treatments. Results for the nitrifying and denitrifying gene abundance, however, revealed a general trend across the biochar materials; the abundance of amoA, nirK, and nos $Z$ were the highest in WS biochar-amended soil and lowest in soils amended with SWC biochar. WS biochar significantly increased the abundance of amo $A$ gene by $45 \%$ whereas SWC decreased it by $65 \%$, compared to control. Additionally, biochar W410 decreased amoA abundance by $38 \%$ compared to control. For the abundance of the denitrifying gene nirK, WS biochar-amended soil significantly increased (40\%) and SWC biochar decreased (26\%) numbers compared to the control. The abundance of nos $Z$ gene was increased by $32 \%$ in WS treatment and significantly decreased by $48 \%$ in SWC treatment relative to the control. None of the biochar treatments altered the abundance of denitrifier gene nirS. To better understand how biochar materials influenced the composition of denitrifier community, we also 
Table 4 Soil $\mathrm{pH}$, cation exchange capacity (CEC), gross mineralization, gross nitrification, net nitrification, and cumulative $\mathrm{N}_{2} \mathrm{O}$ emissions in biocharamended soil after 42 days of lettuce growing period

\begin{tabular}{|c|c|c|c|c|c|c|}
\hline & Soil pH & $\begin{array}{l}\text { Soil CEC } \\
\left(\mathrm{meq} 100 \mathrm{~g}^{-1}\right)\end{array}$ & $\begin{array}{l}\text { Gross mineralization } \\
\left(\mu \mathrm{g} \mathrm{g} \mathrm{g}^{-1} \text { soil day }^{-1}\right)\end{array}$ & $\begin{array}{l}\text { Gross nitrification } \\
\left(\mu \mathrm{g} \mathrm{N} \mathrm{g}^{-1} \text { soil day }^{-1}\right)\end{array}$ & $\begin{array}{l}\text { Net nitrification } \\
\left(\mu \mathrm{g} \mathrm{N} \mathrm{g}^{-1} \text { soil day }^{-1}\right)\end{array}$ & $\begin{array}{l}\text { Cumulative } \mathrm{N}_{2} \mathrm{O} \\
\left(\mathrm{kg} \mathrm{N}_{2} \mathrm{O}-\mathrm{N} \mathrm{ha}^{-1}\right)\end{array}$ \\
\hline Control & $6.7 \pm 0.1$ & $33.5 \pm 2.3$ & $2.1 \pm 0.1$ & $1.3 \pm 0.5$ & $0.2 \pm 0.0$ & $0.6 \pm 0.1$ \\
\hline W410 & $6.8 \pm 0.0$ & $37.7 \pm 7.1$ & $5.5 \pm 0.9^{*}$ & $0.8 \pm 0.3$ & $0.2 \pm 0.0$ & $0.5 \pm 0.1$ \\
\hline W510 & $6.9 \pm 0.1$ & $35.9 \pm 6.5$ & $3.8 \pm 0.3^{*}$ & $1.3 \pm 0.1$ & $0.4 \pm 0.0^{*}$ & $0.3 \pm 0.0$ \\
\hline $\mathrm{PC}$ & $6.8 \pm 0.1$ & $27.6 \pm 0.8$ & $3.2 \pm 0.1$ & $0.7 \pm 0.3$ & $0.4 \pm 0.0 *$ & $0.7 \pm 0.3$ \\
\hline SWC & $6.8 \pm 0.1$ & $27.2 \pm 4.1$ & $4.0 \pm 0.1 *$ & $1.1 \pm 0.2$ & $0.2 \pm 0.0$ & $0.4 \pm 0.1$ \\
\hline WS & $7.5 \pm 0.2^{*}$ & $55.0 \pm 0.6^{*}$ & $1.8 \pm 0.1$ & $1.0 \pm 0.2$ & $0.4 \pm 0.0 *$ & $0.4 \pm 0.0$ \\
\hline
\end{tabular}

Values are means \pm standard errors $(n=3)$

*Mean values significantly different from control (Dunnett's test, $p<0.05$ )

calculated combinations of the ratios of $\mathrm{N}_{2} \mathrm{O}$ reducer abundance to $\mathrm{N}_{2} \mathrm{O}$ producer abundance (Fig. 2): nos Z/(nirK+nirS), nos $Z /($ nirK $)$, and nos $Z /(n i r S)$. The highest nos $Z /(n i r K+n i r S)$ and nosZ/nirS ratios were found in the WS biochar treatment, indicating a higher relative abundance of $\mathrm{N}_{2} \mathrm{O}$ reducers to $\mathrm{N}_{2} \mathrm{O}$ producers. Dunnett means separation test also revealed that SWC decreased the ratio of $n o s Z /($ nir $S+$ nirK $)$ relative to the non-amended control soil, indicating a lower relative abundance of $\mathrm{N}_{2} \mathrm{O}$ reducers to $\mathrm{N}_{2} \mathrm{O}$ producers. The nos $Z$ / nirK ratio was not significantly affected by any of the biochar treatments.

Correlation analyses for functional genes and biocharrelated properties are presented in Table 5. The abundance of bacterial 16S rDNA gene positively correlated with biochar $\mathrm{pH}$, biochar ash content, and soil $\mathrm{pH}$. Abundances of nirK gene also correlated with biochar $\mathrm{pH}$, ash content, soil $\mathrm{pH}$, and soil CEC. The abundance of amo $A$ gene positively correlated with biochar ash content and soil $\mathrm{pH}$, but negatively correlated with biochar $\mathrm{H} / \mathrm{C}$ ratio. NosZ correlated well with soil CEC. The abundance of nirS gene did not correlate with any of the biochar and soil properties.

\section{Discussion}

Among the measured biochar and soil parameters, gross mineralization rates positively correlated with $\mathrm{H} / \mathrm{C}$ ratio, itself inversely proportional to biochar's aromaticity and recalcitrance (Hammes et al. 2008; Krull et al. 2009). We suggest that less recalcitrant chars presenting high $\mathrm{H} / \mathrm{C}$ ratios (i.e., W410, W510, and SWC) increase mineralization rates, as they are more likely to be decomposed and thereby free up

Table 5 Pearson correlation coefficient for the relationships among bacterial gene abundance, biochar, and biochar-amended soil properties

\begin{tabular}{|c|c|c|c|c|c|c|c|c|c|c|c|c|c|}
\hline & $\begin{array}{l}\text { Biochar } \\
\text { pH }\end{array}$ & $\begin{array}{l}\text { Biochar } \\
\text { ash }\end{array}$ & $\begin{array}{l}\text { Biochar } \\
\mathrm{H} / \mathrm{C}\end{array}$ & Soil pH & Soil CEC & 16S rDNA & amo $A$ & nirK & nirs & nos $Z$ & Cum. $\mathrm{N}_{2} \mathrm{O}$ & G. mineraliz. & Net nitrif. \\
\hline Biochar pH & - & - & - & - & - & - & - & - & - & - & - & - & - \\
\hline Biochar ash & $0.99 * *$ & - & - & - & - & - & - & - & - & - & - & - & - \\
\hline B. $\mathrm{H} / \mathrm{C}$ & NS & NS & - & - & - & - & - & - & - & - & - & - & - \\
\hline Soil pH & $0.93^{*}$ & $0.93 *$ & $-0.64 * *$ & - & - & - & - & - & - & - & - & - & - \\
\hline Soil CEC & NS & NS & NS & $0.92 *$ & - & - & - & - & - & - & - & - & - \\
\hline $16 \mathrm{~S}$ rDNA & $0.98 * *$ & $0.99 * *$ & NS & $0.92 *$ & NS & - & - & - & - & - & - & - & - \\
\hline amoA & ns & $0.92 *$ & $-0.70 * *$ & $0.93^{*}$ & NS & $0.93 *$ & - & - & - & - & - & - & - \\
\hline $\operatorname{nir} K$ & $0.97 * *$ & $0.98 * *$ & NS & $0.97 * *$ & $0.89 *$ & $0.95 *$ & $0.91^{*}$ & - & - & - & - & - & - \\
\hline nirS & NS & NS & NS & NS & $0.91^{*}$ & NS & $0.91^{*}$ & NS & - & - & - & - & - \\
\hline $\operatorname{nos} Z$ & NS & NS & NS & NS & NS & NS & $0.91^{*}$ & NS & NS & - & - & - & - \\
\hline Cum. $\mathrm{N}_{2} \mathrm{O}$ & NS & NS & NS & NS & NS & NS & NS & NS & NS & NS & - & - & - \\
\hline G. mineraliz & NS & NS & $0.76^{* *}$ & $0.84 * *$ & NS & NS & NS & NS & NS & NS & NS & - & - \\
\hline Net nitrif. & NS & NS & $-0.82 * *$ & NS & NS & NS & NS & NS & NS & NS & NS & NS & - \\
\hline
\end{tabular}

${ }^{*} p<0.05 ; * *<<0.01$

$N S$ non-significant, $B . H / C$ biochar $\mathrm{H} / \mathrm{C}$ ratio, Cum. $\mathrm{N}_{2} \mathrm{O}$ cumulative $\mathrm{N}_{2} \mathrm{O}$ emissions, G. mineralization gross mineralization, Net nitrif. net nitrification 


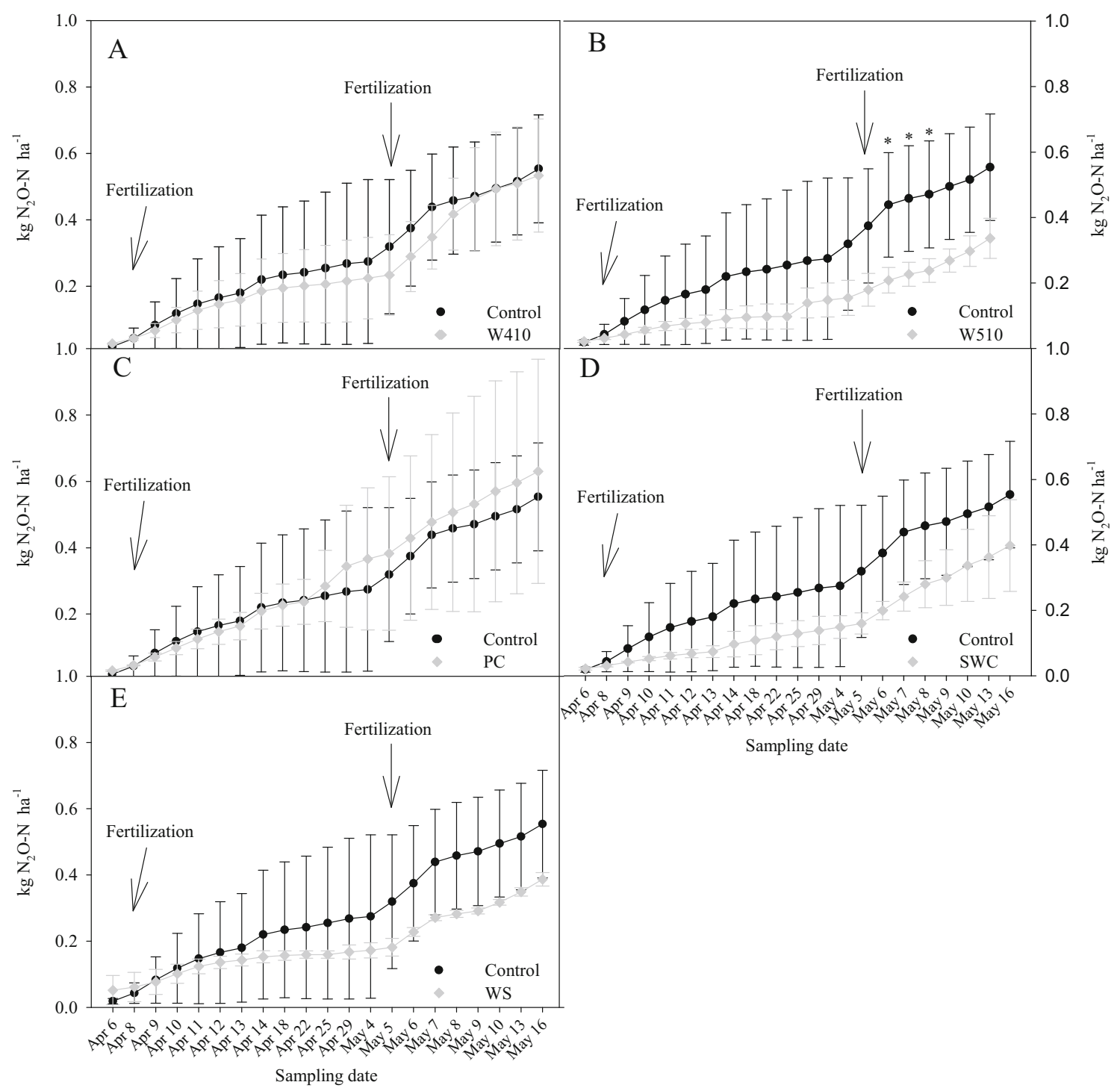

Fig. 1 Cumulative $\mathrm{N}_{2} \mathrm{O}$ fluxes over 42 days in biochar-amended soil under lettuce cultivation. Mean values with asterisks are significantly different from control (Dunnett's test, $p<0.05)$. Error bars indicate standard deviation of the mean $(n=3)$

Table 6 Abundance of total bacterial (16S rDNA), nitrifying (amoA), and denitrifying (nirK, nirS, and nosZ) genes in soil amended with different biochar materials expressed as number of gene copies per gram of soil

\begin{tabular}{llclrl}
\hline & \multicolumn{1}{l}{$\begin{array}{l}\text { 16S rDNA } \\
\left(10^{6} \text { copies } \mathrm{g}^{-1} \text { soil }\right)\end{array}$} & & nirK & \multicolumn{1}{l}{ nirS } & nosZ \\
\hline Control & $862 \pm 73$ & $21 \pm 2.7$ & $3.4 \pm 0.1$ & $11 \pm 1.8$ & $6 \pm 0.4$ \\
W410 & $621 \pm 2.4$ & $13 \pm 0.8^{*}$ & $2.7 \pm 0.6$ & $10 \pm 1.5$ & $6 \pm 0.6$ \\
W510 & $669 \pm 87$ & $17 \pm 1.1$ & $2.6 \pm 0.6$ & $8 \pm 0.9$ & $5 \pm 0.9$ \\
PC & $759 \pm 70$ & $17 \pm 2.8$ & $2.9 \pm 0.3$ & $9 \pm 1.0$ & $5 \pm 0.2$ \\
SWC & $631 \pm 256$ & $7 \pm 0.7^{*}$ & $2.5 \pm 0.5$ & $7 \pm 1.3$ & $3 \pm 1.0^{*}$ \\
WS & $954 \pm 158$ & $31 \pm 0.7^{*}$ & $4.9 \pm 0.1^{*}$ & $11 \pm 2.3$ & $8 \pm 1.9$ \\
\hline
\end{tabular}

Values are means \pm standard errors $(n=3)$

*Significantly different from control (Dunnett's test, $p<0.05$ )
$\mathrm{N}$ trapped in the char into the mineral pool (Mukherjee and Zimmerman 2013). Whether the amount of $\mathrm{N}$ mineralized in this method represents the majority of mineralization, or represents a priming function for the bulk soil as reported in other studies (Wardle et al. 2008, Zimmerman et al. 2011) may require a full accounting of the $\mathrm{N}$ pools.

Net nitrification increased twofold in soils amended with W510, PC, and WS biochars. A higher net nitrification rate indicates higher $\mathrm{N}$ availability for plant uptake or for losses via denitrification or leaching (Piccolo et al. 1994; Singla et al. 2014). Song et al. (2014) performed a thorough study of the nitrification process and revealed that potential ammonia oxidation was sustained for 2 weeks longer in biochar-amended soils than in control soils (alkaline coastal soil). They associate this effect to an increased abundance of nitrifying bacteria and archaea in biochar-amended soils. In our study, out of the 


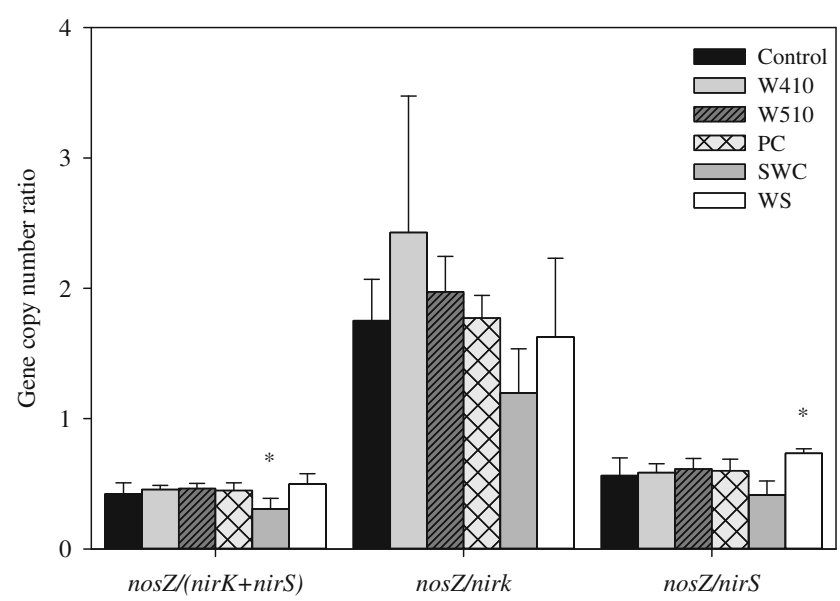

Fig. 2 Ratios of nosZ/(nirK+nirS), nosZ/nirK, and nosZ/nirS in biocharamended soil under lettuce cultivation. Mean values with asterisks are significantly different from control within ratio group (Dunnett's test, $p<0.05)$. Error bars indicate standard deviation of the mean $(n=3)$

biochar materials that increased net nitrification, only WS significantly increased bacterial $a m o A$ abundance. Although bacterial amoA is more abundant than archaeal amoA in soils, Song et al. (2014) suggested that there is a stronger correlation to nitrification with the latter, and this may be good cause for investigation of archaea nitrification with respect to biochar.

Increases in gross mineralization and net nitrification rates were not translated into increments in plant biomass. Sun et al. (2014) suggests that biochar effects on plant production may be more pronounced in deprived agroecosystems than in nonacidic and fertile soils. Additionally, Sun et al. (2014) suggests that biochar effects may be compromised by sufficient fertilization, which was the case for these mesocosms that received $190 \mathrm{~kg} \mathrm{ha}^{-1}$ to reproduce the rates used by lettuce producers in the state of California (Rosenstock et al. 2013).

By altering chemical, physical, and hydrological properties of soils, several studies suggest that biochar can decrease $\mathrm{N}_{2} \mathrm{O}$ fluxes (Yanai et al. 2007; Spokas et al. 2009; van Zwieten et al. 2010; Wang et al. 2011; Zheng et al. 2012), but the effects are site and biochar type specific (Spokas and Reicosky 2009). In this study, none of the biochar materials affected the total cumulative emissions of $\mathrm{N}_{2} \mathrm{O}$ (Table 4). Significant effects of biochar on $\mathrm{N}_{2} \mathrm{O}$ fluxes were only detected for a short period of the growing season and in soils amended with W510 biochar. With the techniques used in this study, it was not possible to determine the reason for this temporal decrease in $\mathrm{N}_{2} \mathrm{O}$ emissions as W510 did not seem to limit $\mathrm{N}$ availability or restrain the presence of denitrifying microorganisms. Transient effects of biochar on $\mathrm{N}_{2} \mathrm{O}$ emissions observed here are in accordance with previous studies carried out in fertilized and cultivated trails for mid to long term. Castaldi et al. (2011) monitored $\mathrm{N}_{2} \mathrm{O}$ emissions during the growing period of wheat (approximately 60 days) at the field scale. In their study, although emissions in control plots were higher compared with biochar-treated plots, only in two occasions was the difference statistically significant. Similarly, Scheer et al. (2011) found that the effect of biochar on decreasing $\mathrm{N}_{2} \mathrm{O}$ emissions is highly episodic with no effects on net $\mathrm{N}_{2} \mathrm{O}$ flux over the entire sampling period (55 days). They monitored $\mathrm{N}_{2} \mathrm{O}$ fluxes throughout the growing season of ryegrass in an Australian ferrosol and observed that only when fluxes were generally low $\left(<50 \mu \mathrm{g} \mathrm{N}_{2} \mathrm{O}-\mathrm{N} \mathrm{m}^{-2} \mathrm{~h}^{-1}\right)$ and during specific short periods, $\mathrm{N}_{2} \mathrm{O}$ emissions were significantly lower in the biochar-amended plots. The occasional decreases in $\mathrm{N}_{2} \mathrm{O}$ emissions observed in this study highlight the importance of long-term observations to comprehensively capture the effect of biochar on $\mathrm{N}_{2} \mathrm{O}$ emissions.

Using the ${ }^{15} \mathrm{~N}$ gas flux methods, Cayuela et al. (2013) observed that $\mathrm{N}_{2} \mathrm{O} / \mathrm{N}_{2}$ ratio decreased in 15 agricultural soils after biochar amendment, pointing to denitrification as the main pathway for decreases in $\mathrm{N}_{2} \mathrm{O}$ emissions in biocharamended soils, by enhancing the reduction of $\mathrm{N}_{2} \mathrm{O}$ to $\mathrm{N}_{2}$. Given the form of fertilizer applied (organic) and the moderately low soil moisture of $20 \%(w / w)$, it is possible that denitrification was not the predominant source of $\mathrm{N}_{2} \mathrm{O}$ in our study; instead, nitrification may have played an important role in producing $\mathrm{N}_{2} \mathrm{O}$. Thus, decreases in $\mathrm{N}_{2} \mathrm{O}$ fluxes from soils amended with W510 could be related to a decline in $\mathrm{N}_{2} \mathrm{O}$ production from nitrification. Future studies should consider investigating the contribution of nitrification and denitrification to $\mathrm{N}_{2} \mathrm{O}$ emission in biochar-amended soils to predict $\mathrm{N}_{2} \mathrm{O}$ mitigation opportunities of biochar.

We assessed the abundance of nitrifying bacterial gene amo $A$ and denitrifying nirK, nirS, and nosZ genes to verify whether differences in nitrification rates and $\mathrm{N}_{2} \mathrm{O}$ emissions could be related to changes in the size of microbial community possessing the different $\mathrm{N}$ cycling genes. Neither nitrification nor $\mathrm{N} 2 \mathrm{O}$ emissions correlated with gene abundance. Similarly, Kong et al. (2010) found that although soil management influenced nitrifying and denitrifying community abundance, changes in community sizes did not relate to changes in mineral $\mathrm{N}$ concentrations, mineralization, and nitrification rates. Gene abundances showed relationships with biochar properties or biochar-induced soil properties. Biochar ash content correlated well with amoA and nirK abundances. A higher abundance of nirK and $n o s Z$ was measured in the WS treatment and correlated well with increases in soil CEC. WS biochar, which significantly increased soil $\mathrm{pH}$, amoA, and nos $Z$, shifted the nosZ/nirS ratio in favor of $\mathrm{N}_{2} \mathrm{O}$ reducers without decreases in $\mathrm{N}_{2} \mathrm{O}$ emissions. Therefore, our data suggest that biochar can alter abundances of $\mathrm{N}$ cycling genes; however, in order to link changes in process rates and functional microorganisms, an assessment of gene expression would be necessary. 


\section{Conclusions}

We investigated the effects of five biochar materials on $\mathrm{N}$ transformations from mesocosm soils representing an organic lettuce production system. Our results indicate that biochar effects are specific to individual soil-biochar combinations. Biochars with high $\mathrm{H} / \mathrm{C}$ ratios showed potential to increase plant $\mathrm{N}$ availability through increases in gross mineralization. This would be beneficial for organic farming systems challenged by insufficient $\mathrm{N}$ mineralization during plant growth. Our study also found minimal effects of biochar on $\mathrm{N}_{2} \mathrm{O}$ emissions from soils. Significant decreases were only observed occasionally during the growing period and for only one biochar material used in this study. Our results confirm that changes in soil properties, microbial community composition, and $\mathrm{N}$ cycling are biochar type specific and biochar effect on $\mathrm{N}_{2} \mathrm{O}$ mitigation is occasional and may not necessarily persist in the long term. It must be noted that these findings were obtained under specific mesocosm conditions representing an organic lettuce production system, and although they are valid for the studied scenario, they should be extrapolated with care to other agroecosystems.

Acknowledgments This research was funded in part by the California Energy Commission. The authors appreciate the National Research Council of Brazil (CNPq) for scholarship to Pereira, E.I.P. We also would like to thank Benjamin Wilde and Silvandro Tonetto de Freitas for laboratory and greenhouse assistance.

\section{References}

ASTM E 1755 - 95 (1995) Standard test method for ash in biomass. Ann Book ASTM Stand 11(05):1243

Barraclough D (1991) The use of mean pool abundances to interpret $15 \mathrm{~N}$ tracer experiments. Plant Soil 131:89-96

Bruun EW, Hauggaard-Nielsen H, Ibrahim N, Egsgaard H, Ambus P, Jensen PA, Dam-Johansen K (2011) Influence of fast pyrolysis temperature on biochar labile fraction and short-term carbon loss in a loamy soil. Biomass Bioenergy 35:1182-1189

Castaldi S, Riondino M, Baronti S, Esposito FR, Marzaioli R, Rutigliano FA, Vaccari FP, Migglieta F (2011) Impact of biochar application to a Mediterranean wheat crop on soil microbial activity and greenhouse gas fluxes. Chemosphere 85:1464-1471

Cayuela ML, Sánchez-Monedero MA, Roig A, Hanley K, Enders A, Lehmann J (2013) Biochar and denitrification in soils: when, how much and why does biochar reduce N2O emissions? Sci Rep 3:1732

Chan K, Van Zwieten L, Meszaros I, Downie A, Joseph S (2008a) Using poultry litter biochars as soil amendments. Soil Res 46:437-444

Chan K, Van Zwieten L, Meszaros I, Downie A, Joseph S (2008b) Agronomic values of greenwaste biochar as a soil amendment. Soil Res 45:629-634

Clough TJ, Bertram JE, Ray J, Condron LM, O'Callaghan M, Sherlock RR, Wells N (2010) Unweathered wood biochar impact on nitrous oxide emissions from a bovine-urine-amended pasture soil. Soil Sci Soc Am J 74:852-860

Clough TJ, Condron LM (2010) Biochar and the nitrogen cycle: introduction. J Environ Qual 39:1218-1223
Clough TJ, Condron LM, Kammann C, Müller C (2013) A review of biochar and soil nitrogen dynamics. Agronomy 3:275-293

Doane TA, Horwáth WR (2003) Spectrophotometric determination of nitrate with a single reagent. Anal Lett 36:2713-2722

Forster JC (1995) Soil nitrogen. In: Alef K, Nannipieri P (eds) Methods in applied soil microbiology and biochemistry. Academic Press, San Diego, pp 79-87

Gaskin J, Steiner C, Harris K, Das K, Bibens B (2008) Effect of lowtemperature pyrolysis conditions on biochar for agricultural use. Trans ASABE 51:2061-2069

Guerrero M, Ruiz M, Alzueta M, Bilbao R, Millera A (2005) Pyrolysis of eucalyptus at different heating rates: studies of char characterization and oxidative reactivity. J Anal Appl Pyrol 74:307-314

Hammes K, Smernik RJ, Skjemstad JO, Schmidt MW (2008) Characterisation and evaluation of reference materials for black carbon analysis using elemental composition, colour, BET surface area and ${ }^{13} \mathrm{C}$ NMR spectroscopy. Appl Geochem 23:2113-2122

Henry S, Baudoin E, López-Gutiérrez JC, Martin-Laurent F, Brauman A, Philippot L (2004) Quantification of denitrifying bacteria in soils by nirKgene targeted real-time PCR. J Microbiol Methods 59:327-335

Henry S, Bru D, Stres B, Hallet S, Philippot L (2006) Quantitative detection of the nos $Z$ gene, encoding nitrous oxide reductase, and comparison of the abundances of $16 \mathrm{~S} r R N A, \operatorname{nar} G$, nirK, and nos $Z$ genes in soils. Appl Environ Microbiol 72:5181-5189

Hutchinson G, Mosier A (1981) Improved soil cover method for field measurement of nitrous oxide fluxes. Soil Sci Soc Am J 45:311-316

Kandeler E, Deiglmayr K, Tscherko D, Bru D, Philippot L (2006) Abundance of narG, nirS, nirK, and nos $Z$ genes of denitrifying bacteria during primary successions of a glacier foreland. Appl Environ Microbiol 72:5957-5962

Karhu K, Mattila T, Bergström I, Regina K (2011) Biochar addition to agricultural soil increased $\mathrm{CH}_{4}$ uptake and water holding capacityresults from a short-term pilot field study. Agric Ecosyst Environ 140:309-313

Kong A, Hristova K, Scow K, Six J (2010) Impacts of different N management regimes on nitrifier and denitrifier communities and $\mathrm{N}$ cycling in soil microenvironments. Soil Biol Biochem 42:1523-1533

Krull E, Baldock JA, Skjemstad J, Smernik R (2009) Characteristics of biochar: organo-chemical properties. In: Lehmann J, Joseph S (eds) Biochar for environmental management: science and technology. Earthscan, London, pp 53-66

Li J, Zepeda L, Gould BW (2007) The demand for organic food in the US: an empirical assessment. J Food Distrib Res 38:54-69

Montzka S, Dlugokencky E, Butler J (2011) Non-CO2 greenhouse gases and climate change. Nature 476:43-50

Mukherjee A, Zimmerman AR (2013) Organic carbon and nutrient release from a range of laboratory-produced biochars and biochar-soil mixtures. Geoderma 193:122-130

Mukome FN, Zhang X, Silva LC, Six J, Parikh SJ (2013) Use of chemical and physical characteristics to investigate trends in biochar feedstocks. J Agric Food Chem 61:2196-2204

Mulvaney R, Yaremych S, Khan S, Swiader J, Horgan B (2004) Use of diffusion to determine soil cation-exchange capacity by ammonium saturation. Commun Soil Sci Plant Anal 35:51-67

Niggli U, Slabe A, Schmid O, Halberg N, Schlüter M (2008) Vision for an Organic Food and Farming Research Agenda 2025. Organic knowledge for the future. Technology Platform Organics. Brussels/Bonn: IFOAM EU Group/ISOFAR. http://orgprints.org/13439/

Okano Y, Hristova KR, Leutenegger CM, Jackson LE, Denison RF, Gebreyesus B, Lebauer D, Scow KM (2004) Application of realtime PCR to study effects of ammonium on population size of ammonia-oxidizing bacteria in soil. Appl Environ Microbiol 70: 1008-1016

Pang X, Letey J (2000) Organic farming challenge of timing nitrogen availability to crop nitrogen requirements. Soil Sci Soc Am J 64: 247-253 
Piccolo MC, Neill C, Cerri CC (1994) Net nitrogen mineralization and net nitrification along a tropical forest-to-pasture chronosequence. Plant Soil 162:61-70

Porteous LA, Armstrong JL, Seidler RJ, Watrud LS (1994) An effective method to extract DNA from environmental samples for polymerase chain reaction amplification and DNA fingerprint analysis. Curr Microbiol 29:301-307

Rogovska N, Laird D, Cruse R, Fleming P, Parkin T, Meek D (2011) Impact of biochar on manure carbon stabilization and greenhouse gas emissions. Soil Sci Soc Am J 75:871-879

Rosenstock T, Liptzin D, Six J, Tomich T (2013) Nitrogen fertilizer use in California: assessing the data, trends and a way forward. Calif Agric 67:68-79

Saarnio S, Heimonen K, Kettunen R (2013) Biochar addition indirectly affects $\mathrm{N}_{2} \mathrm{O}$ emissions via soil moisture and plant $\mathrm{N}$ uptake. Soil Biol Biochem 58:99-106

Scheer C, Grace PR, Rowlings DW, Kimber S, Van Zwieten L (2011) Effect of biochar amendment on the soil-atmosphere exchange of greenhouse gases from an intensive subtropical pasture in northern New South Wales, Australia. Plant Soil 345:47-58

Singh BP, Hatton BJ, Singh B, Cowie AL, Kathuria A (2010) Influence of biochars on nitrous oxide emission and nitrogen leaching from two contrasting soils. J Environ Qual 39:1224-1235

Singla A, Iwasa H, Inubushi K (2014) Effect of biogas digested slurry based-biochar and digested liquid on $\mathrm{N} 2 \mathrm{O}, \mathrm{CO} 2$ flux and crop yield for three continuous cropping cycles of komatsuna (Brassica rapa var. perviridis). Biol Fertil Soils 50:1201-1209

Song Y, Zhang X, Ma B, Chang SX, Gong J (2014) Biochar addition affected the dynamics of ammonia oxidizers and nitrification in microcosms of a coastal alkaline soil. Biol Fertil Soils 50:321-332

Spokas K, Koskinen W, Baker J, Reicosky D (2009) Impacts of woodchip biochar additions on greenhouse gas production and sorption/degradation of two herbicides in a Minnesota soil. Chemosphere 77:574-581

Spokas KA, Cantrell KB, Novak JM, Archer DW, Ippolito JA, Collins HP, Boateng AA, Lima IM, Lamb MC, McAloon AJ, Lentz RD, Nichols KA (2012) Biochar: a synthesis of its agronomic impact beyond carbon sequestration. J Environ Qual 41:973-989

Spokas KA, Reicosky DC (2009) Impacts of sixteen different biochars on soil greenhouse gas production. Ann Environ Sci 3:179-193

Stark JM, Hart SC (1996) Diffusion technique for preparing salt solutions, Kjeldahl digests, and persulfate digests for nitrogen-15 analysis. Soil Sci Soc Am J 60:1846-1855

Steiner C, Teixeira WG, Lehmann J, Nehls T, de Macêdo JLV, Blum WE, Zech W (2007) Long term effects of manure, charcoal and mineral fertilization on crop production and fertility on a highly weathered Central Amazonian upland soil. Plant Soil 291:275-290

Suddick EC, Six J (2013) An estimation of annual nitrous oxide emissions and soil quality following the amendment of high temperature walnut shell biochar and compost to a small scale vegetable crop rotation. Sci Total Environ 465:298-307

Sun Z, Bruun EW, Arthur E, de Jonge LW, Moldrup P, HauggaardNielsen H, Elsgaard L (2014) Effects of biochar on aerobic processes, enzyme activity, and crop yields in two sandy loam soils. Biol Fertil Soils 50:1087-1097

Suzuki MT, Taylor LT, DeLong EF (2000) Quantitative analysis of smallsubunit rRNA genes in mixed microbial populations via 50-nuclease assays. Appl Environ Microbiol 66:4605-4614

Throbäck IN, Enwall K, Jarvis Å, Hallin S (2004) Reassessing PCR primers targeting nirS, nirK and nos $Z$ genes for community surveys of denitrifying bacteria with DGGE. FEMS Microbiol Ecol 49:401417

Throbäck IN (2006) Exploring denitrifying communities in the environment. Dissertation, Swedish University of Agricultural Sciences

Tuomisto H, Hodge I, Riordan P, Macdonald D (2012) Does organic farming reduce environmental impacts?-a meta-analysis of European research. J Environ Manag 112:309-320

Van Zwieten L, Kimber S, Morris S, Downie A, Berger E, Rust J, Scheer $\mathrm{C}$ (2010) Influence of biochars on flux of $\mathrm{N}_{2} \mathrm{O}$ and $\mathrm{CO}_{2}$ from Ferrosol. Soil Res 48:555-568

Verhoeven E, Six J (2014) Biochar does not mitigate field-scale $\mathrm{N}_{2} \mathrm{O}$ emissions in a Northern California vineyard: an assessment across two years. Agric Ecosyst Environ 191:27-38

Wang J, Zhang M, Xiong Z, Liu P, Pan G (2011) Effects of biochar addition on $\mathrm{N} 2 \mathrm{O}$ and $\mathrm{CO} 2$ emissions from two paddy soils. Biol Fertil Soils 47:887-896

Wardle DA, Nilsson MC, Zackrisson O (2008) Fire-derived charcoal causes loss of forest humus. Science 320:629

Willer V, Kilcher L (2012) The World of organic agriculture: statistics and emerging trends 2012. FiBL, IFOAM

Yanai Y, Toyota K, Okazaki M (2007) Effects of charcoal addition on $\mathrm{N} 2 \mathrm{O}$ emissions from soil resulting from rewetting air-dried soil in short-term laboratory experiments. Soil Sci Plant Nutr 53:181-188

Zheng J, Stewart CE, Cotrufo MF (2012) Biochar and nitrogen fertilizer alters soil nitrogen dynamics and greenhouse gas fluxes from two temperate soils. J Environ Qual 41:1361-1370

Zimmerman AR, Gao B, Ahn MY (2011) Positive and negative carbon mineralization priming effects among a variety of biochar-amended soils. Soil Biol Biochem 43:1169-1179 